\title{
Musculo-Skeletal Injuries in Jeddah Industrial State, Saudi Arabia
}

\author{
ABDULLAH H. A. JUMA, FRCS(ED) \\ Department of Orthopaedic Surgery, Faculty of Medicine \& Allied Sciences, \\ King Abdulaziz University, Jeddah, Saudi Arabia
}

\begin{abstract}
A retrospective analysis of 350 industrial injuries in a population of 12,828 workers was carried out in the Industrial State of Jeddah, Saudi Arabia with the objectives of evaluating injuries in relation to the characteristics of workers, materials, tools, work environment, and tasks. Data were collected by field surveillance, examining patients, notifying different factors, computing them and then analyzing using statistical analysis. Significant relationships were found in risk factors such as young age $(\mathrm{P}<0.0001)$, low level of education $(\mathrm{P}<0.001)$, short experience $(\mathrm{P}<0.0001)$, solid materials of average and overweight and sizes $\leq 1 \mathrm{~m}^{2}$ ( $\left.\mathrm{P}<0.0001\right)$, low energy and high velocity tools $(\mathrm{P}<0.0001)$, machine handling $(\mathrm{P}<0.05)$, and inadequate safety measures $(\mathrm{P}$ $<0.000 \mathrm{I}$ ), respectively. Preventive measures were constructed accordingly. These should be implemented in the occupational field to minimize the great loss at work.

Keywords: Industrial injuries, Characteristics, Risk factors, Prevention.
\end{abstract}

\section{Introduction}

Industries are growing and expanding very fast all over the world with highly competitive markets and consumptions. Hence, musculo-skeletal injuries of occupational and industrial backgrounds form a significant part of orthopaedic practicer1]. With some, they are considered second to cardiovascular diseases' in causing disability and great loss of working days[2]. Not only that, but about 350/0 of total injuries were reported to be due to occupational hand and finger injuries by the Massachusetts Medical Society in 1982[31. However, different factors contribute in causing injuries and their relative risks. Indentification of the different factors and their characteristics were reported in several studies ${ }^{14-6}$ ]. They aimed at the maintenance of safety and prevention of accidents at work.

Correspondence \& reprint requests to: Dr. A.H. A. Juma, P.O. Box 6615, Jeddah 21433, Saudi Arabia. Accepted for publication: 04 June 1997. Received: 10.February 1997. 
The present study was designed to identify the relative significance of the various characteristics of the different factors that were the cause of injuries among workers in the Industrial State of the city of Jeddah over a period of one year.

\section{Subjects and Methods}

The Industrial State in the city of Jeddah, Saudi Arabia was established 1968 in the southern district and 8 kilometers from the city centre. It was divided into different zones and stages with a total size of 12 million square meters. There were 200 types of industries involving food, leather, clothing, plastics, furniture, cables, electronics, papers, chemicals, steel, and confectioneries, The work settings were satisfactory, safe, and well-organized. There were 12,828 male workers distributed among these industries. No females were found to work due to the rules and regulations of the country. There was a safety and security department of the General Directorate of Civil Defence responsible for the supervision and maintenance of safety in the various sections of the Industrial State. A primary health care clinic was found to provide first aid, general health care, and referral to the other centres and hospitals whenever indicated.

A retrospective computer search, field surveillance, and regular visits to the area were performed for each case of industrial injury. The data were collected with the assistance of the above mentioned authorities and then statistically analyzed (using $X^{2}$ testing and other appropriate statistical methods) to observe their significance.

\section{Results}

The total number of accidents reported in a period of one year was 350 (2.730/0) in a population of 12,828 workers in the industrial state. Hence, 12,478 workers had no accidents during the same period. The distribution of accidents and accident rate percentage by the characteristics of workers, material, tools, work environment, and tasks were analyzed and presented in Tables 1 to 5. In the analysis, factors of important relevance to the characteristics and accidents were described.

Table 1 describes age, nationality, length of experience, education, communication (language), fatigue, exertion, and physical build. The young age group showed statistical significance in relation to industrial injuries $(\mathrm{P}<0.0001)$ (Table 1). Similar observation was noted in relation to a low level of education $(\mathrm{P}<0.001)$ (Table 1).

TABIE: 1. Distribution of accidents and accident rate percentages by the characteristics of worker.

\begin{tabular}{|c|c|c|c|c|c|}
\hline \multirow{2}{*}{\multicolumn{2}{|c|}{ Characteristic }} & & Accidents & & \multirow{2}{*}{$\begin{array}{c}\text { Accident Rate } \\
\text { Percent }\end{array}$} \\
\hline & & Present & Absent & Total & \\
\hline \multirow[t]{5}{*}{ Age (years) } & $20-29$ & 196 & 2,479 & 2,675 & 7.3 \\
\hline & $30-39$ & 112 & 5,930 & 6,042 & 1.9 \\
\hline & $40+$ & 42 & 4,069 & 4,111 & 1.0 \\
\hline & Total & 350 & 12,478 & 12,828 & 3.0 \\
\hline & Chi sq $=275.70$ & & $\mathrm{dJ} .=2$ & $\mathrm{P}>0.0001$ & (N.S.) \\
\hline
\end{tabular}


TABLIE I. Contd

\begin{tabular}{|c|c|c|c|c|c|}
\hline \multirow{2}{*}{\multicolumn{2}{|c|}{ Characteristic }} & \multirow[b]{2}{*}{ Present } & \multirow{2}{*}{$\frac{\text { Accidents }}{\text { Absent }}$} & & \multirow{2}{*}{$\begin{array}{c}\text { Accident Rate } \\
\text { Percent }\end{array}$} \\
\hline & & & & Total & \\
\hline \multirow[t]{4}{*}{ Nationality } & Saudi & 29 & 1,123 & 1,152 & 2.5 \\
\hline & Non-Saudi & 321 & 11,355 & 11,676 & 2.7 \\
\hline & Total & 350 & 12,478 & 12,828 & 3.0 \\
\hline & Chi sq $=0.21$ & & d.f $=I$ & $\mathrm{P}<0.05$ & (N.S.) \\
\hline \multirow[t]{5}{*}{ Education } & Illiterate & 18 & 1,038 & 1,056 & 1.7 \\
\hline & Primary \& Elem. & 210 & 5,817 & 6,027 & 3.5 \\
\hline & Secondary + & 122 & 5,623 & 5,745 & 1.8 \\
\hline & Total & 350 & 12,478 & 12,828 & \\
\hline & Chi sq $=25.07$ & & d.f. $=2$ & $\mathrm{P}<0.001$ & \\
\hline \multirow{5}{*}{$\begin{array}{l}\text { Length of Experience } \\
\text { (Years) }\end{array}$} & $<\mathrm{I}$ & 163 & 2,471 & 2,634 & 1.1 \\
\hline & $1-5$ & 116 & 3,741 & 3,857 & 3.0 \\
\hline & $<5$ & 71 & 6,266 & 6,337 & 1.1 \\
\hline & Total & 350 & 12,478 & 12,828 & \\
\hline & Chi sq $=181.68$ & & d.f $=1$ & $\mathrm{P}<0.05$ & (N.S.) \\
\hline \multirow{4}{*}{$\begin{array}{l}\text { Communication } \\
\text { (Language) }\end{array}$} & Arabic & 99 & 4,084 & 4,183 & 2.4 \\
\hline & Non-Arabic & 251 & 8,394 & 8,645 & 2.9 \\
\hline & Total & 350 & 12,478 & 12,828 & \\
\hline & Chi $\mathrm{sq}=3.059$ & & d.f. $=1$ & $\mathrm{P}<0.001$ & \\
\hline \multirow[t]{4}{*}{ Fatigue \& Exertion } & Yes & 18 & 2,560 & 2,578 & 0.7 \\
\hline & No & 332 & ,9,918 & 10,250 & 3.2 \\
\hline & Total & 350 & 12,478 & 12,828 & 3.0 \\
\hline & Chi sq $=50.11$ & & d.f $=I$ & $\mathrm{P}<0.0001$ & \\
\hline \multirow[t]{4}{*}{ Physical Build } & Good & 231 & 7,360 & 7,591 & 3.0 \\
\hline & Average & 119 & 12,478 & 12,828 & 2.3 \\
\hline & Total & 350 & 12,478 & 12.828 & 3.0 \\
\hline & Chi sq $=6.94$ & & d.f. $=1$ & $\mathrm{P}<0.05$ & \\
\hline
\end{tabular}

d.f. $=$ degrees of freedom; $N S=$ not significant; $X^{2}=$ Chi-square

Contrary to what is to be expected, more accidents occurred in the absence of fatigue and exertion (3.2\%) and in workers with good physical build (3.0\%) (Table 1). The body build was taken in relation to the height to categorize it into poor body build. Table 2 shows the results on body weight, size, sharp edges, and form and it was found that sharp edges material contributed insignificantly to injuries. Instead, more injuries occurred with non-sharp edge objects (13.5\%) (Table 2). However, a significant relationship was found with average to overweight materials of $\leq 1 \mathrm{~m}^{2}$ size and of solid form ( $\mathrm{P}<0.0001$ and $\mathrm{P}<0.0001$, respectively) (Table 2). The criteria taken for the weight of materials to be light, average, or non-weight was considered with the square meter of its size. 
TABLE 2. Distribution of accidents and accident rate percentages by the characteristics of material.

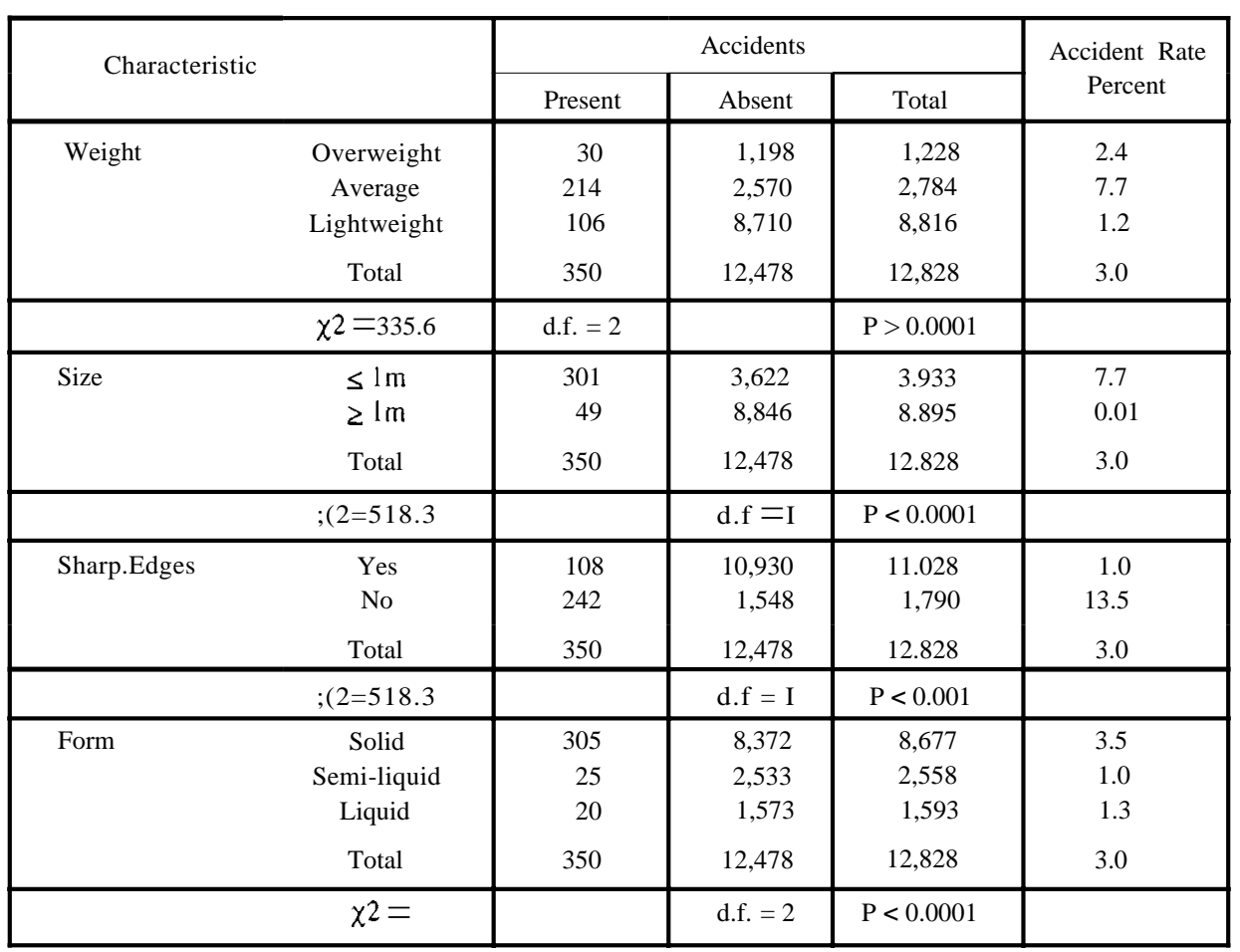

d.f $=$ degrees of freedom; $N S=$ not significant; $X^{2}=$ Chi-square

The factors related to tools and machines are shown in Table 3. A significant relationship was found in tools of low energy and high velocity and in machine handling $(\mathrm{P}<0.000 \mathrm{I}$ and $\mathrm{P}<0.05$, respectively). Mechanical failure did not contribute significantly to injuries (Table 3 ) as maintenance was closely observed at work. Similarly, the design of tools and machines was convenient and safe, hence less accidents occurred in an unsafe design (0.90/0). The work environment was closely screened. The general settings and design of the work environment was satisfactory, hence accidents had no significant relationship to dust, noise, gases, or the design and organization of the workplace (Table 4). Definitely, inconvenient electrical, water, and sewage supplies had a significant relationship to injuries $(\mathrm{P}<0.0001)$ (Table 4).

Although the temperature control and conditioning were convenient, more accidents were reported in a satisfactory atmosphere (2.80/0) (Table 4). However, an important factor of definite risk to the worker was noted to be unsatisfactory safety measures $(\mathrm{P}<0.0001)$ (Table 4). The safety measures were categorized into satisfactory and unsatisfactory according to the procedures taken at work by the characteristics of the tasks. Table 5 revealed that the characteristics of the tasks that were of importance to the risk factors in causing injuries including machine and material handling $(2.5 \%$ and $10.8 \%$, respectively). Finally, upper limb injuries predominated (67\%) as well as cut and penetrating wounds (900/0) (see Figures 1 and 2, respectively). 
TABLE 3. Distribution of accidents and accident rate percentages by characteristics of tools.

\begin{tabular}{|c|c|c|c|c|c|}
\hline \multirow{2}{*}{ Characteristic } & & \multicolumn{3}{|c|}{ Accidents } & \multirow{2}{*}{$\begin{array}{l}\text { Accident Rat } \\
\text { Percent }\end{array}$} \\
\hline & & Present & Accidents & Total & \\
\hline Design & $\begin{array}{c}\text { Convenient \& Safe } \\
\text { Unsafe } \\
\text { Total }\end{array}$ & $\begin{array}{c}343 \\
7 \\
350\end{array}$ & $\begin{array}{c}11.691 \\
787 \\
12.478\end{array}$ & $\begin{array}{c}12,034 \\
794 \\
12,828\end{array}$ & $\begin{array}{l}2.9 \\
0.9 \\
3.0\end{array}$ \\
\hline & $\chi^{2}=10.88$ & d.f. $=1$ & & $\mathrm{P}>0.005$ & \\
\hline $\begin{array}{l}\text { Energy (E) \& Velocity } \\
\text { (V) }\end{array}$ & $\begin{array}{c}\text { High E\&V } \\
\text { Low E\&V } \\
\text { Low E \& High V } \\
\text { Total }\end{array}$ & $\begin{array}{c}9 \\
46 \\
295 \\
350\end{array}$ & $\begin{array}{l}8,348 \\
1.635 \\
2.495 \\
12.478\end{array}$ & $\begin{array}{l}8,357 \\
1,681 \\
2,790 \\
12,828\end{array}$ & $\begin{array}{l}0.1 \\
2.7 \\
10.6 \\
3.0\end{array}$ \\
\hline & $\chi^{2}=863.3$ & d.f $=1$ & & $\mathrm{P}<\mathrm{O} . \mathrm{I}$ & \\
\hline Mechanical Failure & $\begin{array}{c}\text { Yes } \\
\text { No } \\
\text { Total } \\
\end{array}$ & $\begin{array}{c}6 \\
344 \\
350 \\
\end{array}$ & $\begin{array}{c}406 \\
12,072 \\
12,478 \\
\end{array}$ & $\begin{array}{c}412 \\
12,416 \\
12,828 \\
\end{array}$ & $\begin{array}{l}1.5 \\
2.8 \\
3.0 \\
\end{array}$ \\
\hline & $\chi^{2}=2.59$ & d.f $=1$ & & $\mathrm{P}<0.1$ & (N.S.) \\
\hline Machine Handling & $\begin{array}{c}\text { Manual } \\
\text { Other } \\
\text { Total } \\
\end{array}$ & $\begin{array}{c}235 \\
115 \\
350 \\
\end{array}$ & $\begin{array}{l}9,109 \\
3,369 \\
12,478 \\
\end{array}$ & $\begin{array}{l}9,344 \\
12,828 \\
12,878 \\
\end{array}$ & $\begin{array}{l}2.5 \\
3.3 \\
3.0 \\
\end{array}$ \\
\hline & $\chi^{2}=5.90$ & d.f $=I$ & & $\mathrm{P}<0.05$ & \\
\hline
\end{tabular}

d.f $=$ degrees of freedom; NS $=$ not significant; $\boldsymbol{\chi}^{2}=$ Chi-square.

TABLE 4. Distribution of accidents and accident rate percentages by the characteristics of work environment.

\begin{tabular}{|c|c|c|c|c|c|}
\hline \multirow{2}{*}{\multicolumn{2}{|c|}{ Characteristic }} & & Accidents & & \multirow{2}{*}{$\begin{array}{l}\text { Accident Rate } \\
\text { Percent }\end{array}$} \\
\hline & & Present & Accidents & Total & \\
\hline \multirow[t]{2}{*}{$\begin{array}{l}\text { Electrical, Water \& Sew- } \\
\text { age Supply }\end{array}$} & $\begin{array}{l}\text { Inconvenient } \\
\text { Convenient } \\
\text { Total }\end{array}$ & $\begin{array}{r}46 \\
304 \\
350\end{array}$ & $\begin{array}{r}774 \\
117,041 \\
12.478\end{array}$ & $\begin{array}{r}820 \\
12,008 \\
12,828\end{array}$ & $\begin{array}{l}5.6 \\
2.5 \\
3.0\end{array}$ \\
\hline & $\chi^{2}=27.4$ & d.f. $=1$ & & $\mathrm{P}<0.0001$ & \\
\hline \multirow[t]{2}{*}{$\begin{array}{l}\text { Temperature Control \& } \\
\text { Conditioning }\end{array}$} & $\begin{array}{c}\text { Satisfactory } \\
\text { Unsatisfactory } \\
\text { Total } \\
\end{array}$ & $\begin{array}{r}331 \\
19 \\
350 \\
\end{array}$ & $\begin{array}{r}11,343 \\
1,135 \\
12,478 \\
\end{array}$ & \begin{tabular}{r|}
11.674 \\
1,154 \\
12,828 \\
\end{tabular} & $\begin{array}{l}2.8 \\
1.6 \\
3.0 \\
\end{array}$ \\
\hline & $\chi^{2}=5.59$ & d.f. $=1$ & & $\mathrm{P}<0.05$ & \\
\hline \multirow[t]{2}{*}{ Dust, Noises, \& Gases } & $\begin{array}{c}\text { Well Controlled } \\
\text { Needs Regular Checkup } \\
\text { Total } \\
\end{array}$ & $\begin{array}{r}340 \\
10 \\
350 \\
\end{array}$ & $\begin{array}{c}12,067 \\
411 \\
12,478 \\
\end{array}$ & $\begin{array}{r}12,407 \\
421 \\
12,828 \\
\end{array}$ & $\begin{array}{l}2.7 \\
2.4 \\
3.0 \\
\end{array}$ \\
\hline & $\chi^{2}=3.53$ & d.f $=I$ & & $\mathrm{P}<0.05$ & (N.S.) \\
\hline \multirow[t]{2}{*}{ Design \& Organisation } & $\begin{array}{c}\text { Convenient } \\
\text { Inconvenient } \\
\text { Total } \\
\end{array}$ & $\begin{array}{r}324 \\
26 \\
350 \\
\end{array}$ & $\begin{array}{r}11,162 \\
1,316 \\
12,478 \\
\end{array}$ & $\begin{array}{r}11,486 \\
1,342 \\
12,828 \\
\end{array}$ & $\begin{array}{l}2.8 \\
1.9 \\
3.0 \\
\end{array}$ \\
\hline & $\chi^{2}=3.53$ & d.f, $=1$ & & $\mathrm{P}<0.05$ & (N.S.) \\
\hline \multirow[t]{2}{*}{ Safety Measures } & $\begin{array}{c}\text { Satisfactory } \\
\text { Unsatisfactory } \\
\text { Total } \\
\end{array}$ & $\begin{array}{r}309 \\
.41 \\
350 \\
\end{array}$ & $\begin{array}{r}12,260 \\
218 \\
12.478 \\
\end{array}$ & $\begin{array}{r}12,569 \\
259 \\
12,828 \\
\end{array}$ & $\begin{array}{c}2.5 \\
15.8 \\
3.0 \\
\end{array}$ \\
\hline & $\chi^{2}=171.0$ & d.f. $=1$ & d.f. $=1$ & $\mathrm{P}<0.0001$ & \\
\hline
\end{tabular}

d.f $=$ degrees of freedom; $\mathrm{NS}=$ not significant; $\chi^{2}=$ Chi-square. 
TABLE 5. Distribution of accidents by the characteristic of task.

\begin{tabular}{|c|c|c|c|c|}
\hline \multirow{2}{*}{ Task } & \multicolumn{3}{|c|}{ Accident } & \multirow{2}{*}{$\begin{array}{l}\text { Accident Rate } \\
\text { Percentage }\end{array}$} \\
\hline & Present & Absent & Total & \\
\hline $\begin{array}{l}\text { Machine handling } \\
\text { "operating machines" }\end{array}$ & 235 & 9.109 & 9.344 & 2.5 \\
\hline Material handling & 70 & 580 & 650 & 10.8 \\
\hline Driving & 2 & 417 & 419 & 0.5 \\
\hline Lifting & 12 & 654 & 666 & 1.8 \\
\hline Carrying & 8 & 525 & 533 & 1.5 \\
\hline Fastening loads and unfastening & 13 & 831 & 844 & 1.5 \\
\hline Others ${ }^{*}$ & 10 & 362 & 372 & 2.7 \\
\hline
\end{tabular}

*includes falling, slipping, and impact against objects

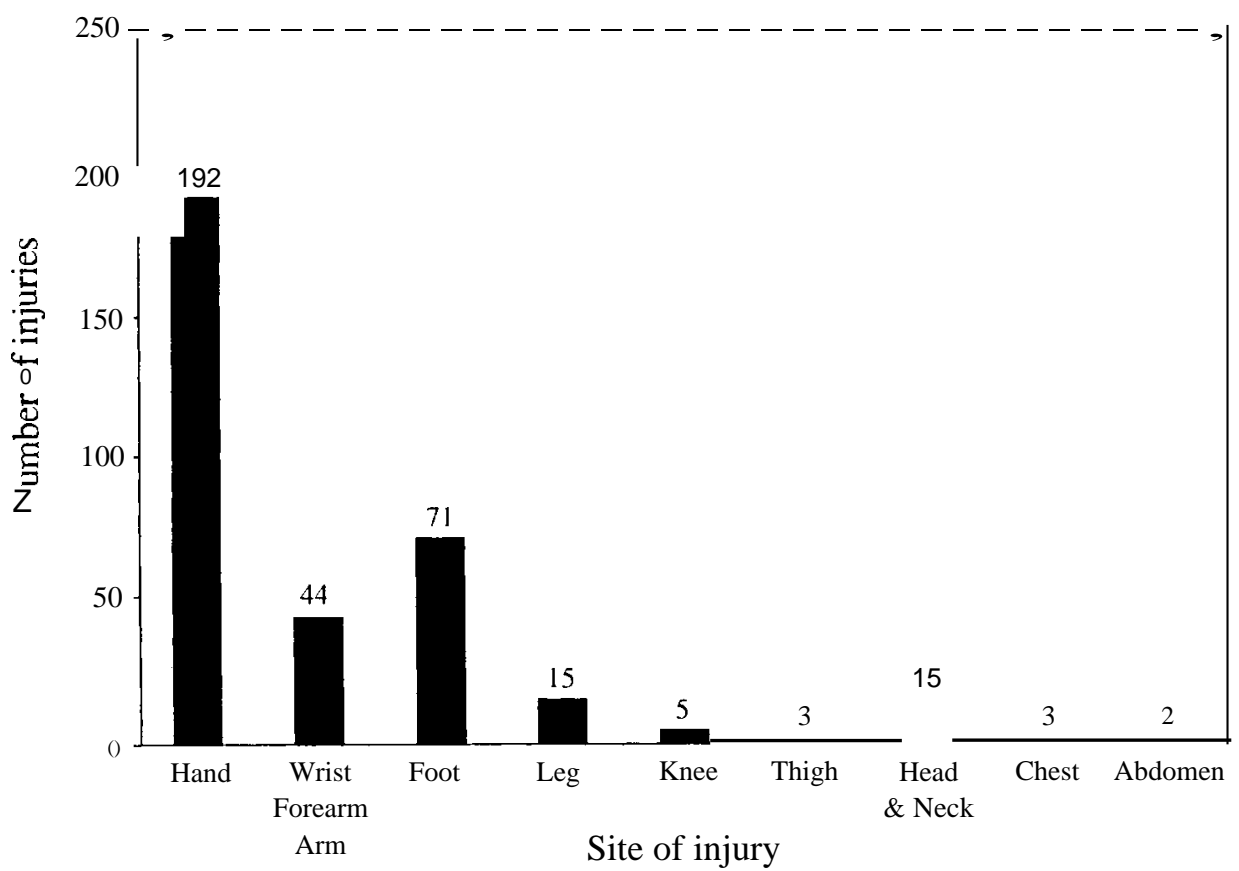

FIG. 1. Distribution of accidents by the site of injury. 


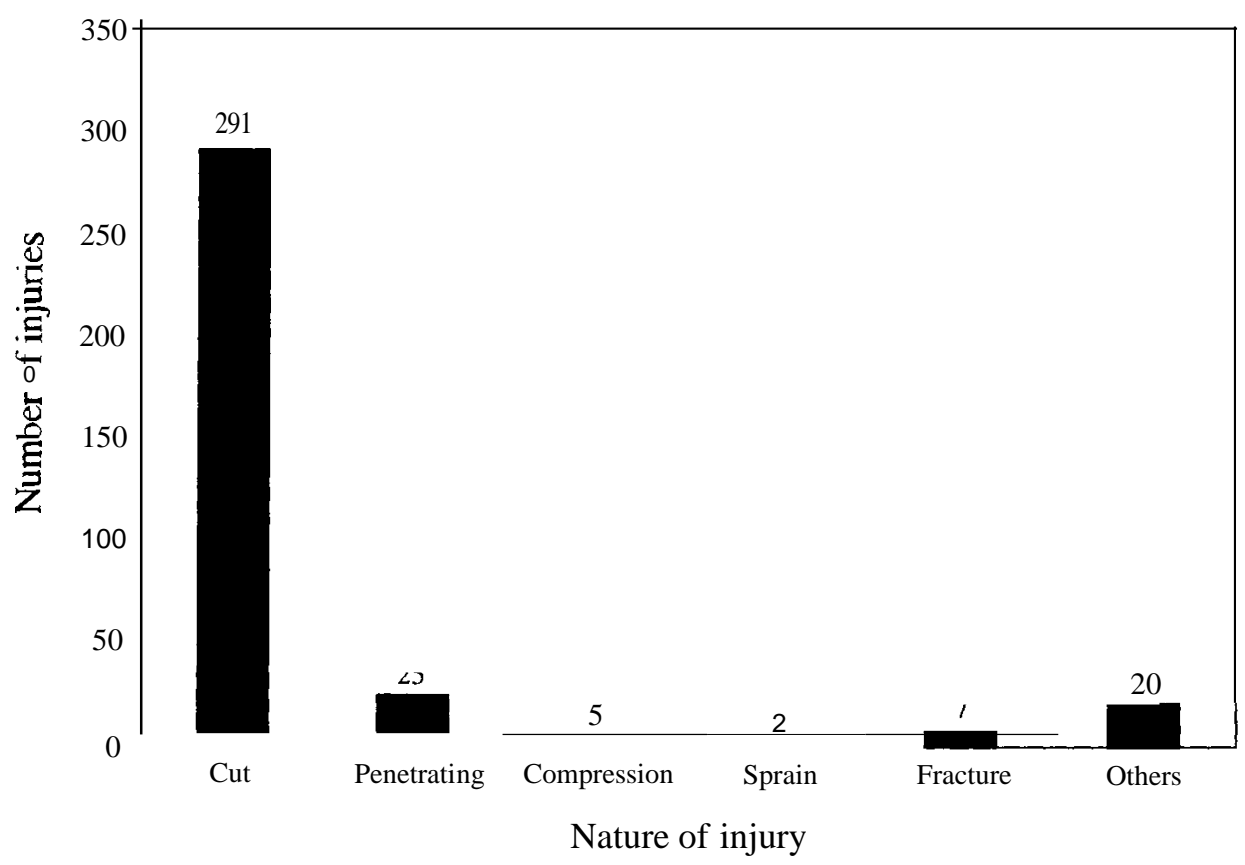

FIG. 2. Distribution of accidents by the nature of injury.

\section{Discussion}

Industrial injuries are crucial in their delirious effect on the health and economy of the society concerned, Their occurrence are multifactorial and there are identifiable risk factors which are closely related. These characteristics are important to investigate while reporting the accident rates at work in industries. In the present study, the characteristics of workers, materials, tools, work environment and tasks were investigated and analyzed into different factors which were of direct relation and importance to work industries. Young age group (20-29) workers were more prone to having accidents and they were at higher risk $(\mathrm{P}<0.000 \mathrm{I})$. The same observation was noted in other studies $[5,7 ; 8,9]$. Not only that, but also noted was a distinct increase in the number of accidents in the age group of 20-39 years. This could be explained by the fact that young people pay less attention to precautions while attending their work; hence, the age by itself is a risk factor. Obviously, the level of education was also contributory and when analyzed, it was found to be related significantly to injuries, particularly a low level of education ( $\mathrm{P}<0.001)$. The latter confirms previously reported studies! 11]. Furthermore, the duration of experience at work also proved to be essential to eliminate the risk factor of short experience which was found significantly related to injuries $(\mathrm{P}<0.000 \mathrm{I})$. This is consistent with the finding that experience is the best predicative value in the surveillance of accidents. in industries[7,10]. However, others noted that in some occupations like woodworking, more accidents occurred in the hands of experienced woodworkers $(37 \%)[11]$. The explanation could be that some other factors may have played a 
major part in causing woodwork injuries such as manual handling and lack of safety measures. The risk factors arising from the materials approached at work were also evaluated regarding their weight, size, and form. These were statistically significant in the average and overweight objects of $\leq 1 \mathrm{~m}^{2}$ size and solid form $(\mathrm{P}<0.0001$ and $\mathrm{P}<0.0001$, respectively). This is consistent with the suggestion that the danger increases linearly with the increasing weight of the load from the equation of potential and kinetic energy $\left(E=m v^{2} / 2\right)[12]$. Hence, the risk factor of objects of such caliber are possible to eliminate if mechanization, automation, and remote control operation are implemented at work. Based on the same quotation of a previous reference that the danger grows proportionally to the square velocity of motion' 12], it was found from the present study that the high velocity tools with low energy had a high accident rate (10.60/0) with significant relationship $(\mathrm{P}<0.0001)$. Not only that, but it was also observed that. tools and machines, when handled manually, carried a high risk factor to worker (2.50/0). In addition, the evaluation of task characteristic also revealed a high accident rate in material handling (10.8\%). This was obvious since handling per se carried a risk factor to workers in industries. This was clearly stated by some authors that $30 \%$ of all occupational accidents were related to material handling and more than half of those occurred in manual operations[4,12].

The work environment had their factors analyzed. A definite risk factor which significantly contributed in causing accidents was unsatisfactory safety measures $(\mathrm{P}<0.000 \mathrm{I})$. This was similarly noted in $58 \%$ of severe occupational hand injuries which were due to inadequate safety provision and inadequate use of safe machines[101. Also reported in woodwork injuries, the significant causal factor was the failure to apply safety and properly installed guards[11]. Needless to say, the importance of adopting safety measures at work definitely lowers accident rates. It was worth to indicate that some factors in the present study had less or no significance such as the nationality, communication of language in workers, and work environment of design, dust, gases and temperature control except electrical and water supply. Nor the personal factors like physical build or fatigue and exhaustion were of any significance. However, the same surveillance was brought up by some authors stating that adverse work environment and personal risk factors were associated with a small proportion of occupational hand injuries!।0]. The sharp edges of materials, together with the design of tools and their mechanical failure, were also of no significance to accidents in this surveillance. Because manual handling is a risk factor, the speculation would be that hand injuries will predominate. This was duly noted in the present study that $67 \%$ of injuries were in the upper limbs and, in particular, the hands. A similar report from the Massachusetts Medical Society in 1982 showed that 350/0 of total injuries were due to occupational hand and finger injuries[3]. Lastly, minor injuries predominated $(90 \%)$ in the present study such as cut and penetrating wounds and this was similar to that of other studies[5].

In conclusion, manual handling of tools and materials and the lack of safety precautions by young, low educated workers with short experience are real risk factors. The solid form of materials with certain sizes and weight, together with high velocity tools, are also risky. The golden rule will be the application of preventive measures such 
as minimal handling by automation, mechanization, and remote control operation. In addition, workers selection, their education, and training are also important. Safety measures should be strictly adopted in the form of safety guards, alarming devices, communication system, protective measures at vulnerable areas, and regular maintenance.

\section{Acknowledgments}

My sincere thanks are expressed to the Administrative and Public Relation Departments of the Industrial State in Jeddah for their kind help and guidance during the field surveillance and data collection. Also, my deep thanks to my colleagues who assisted me in the statistical analysis.

\section{References}

[I] Frymoyer JW, Mooney V. Occupational orthopaedics: in Current Concepts Review. JBJS Am 1986; 3: 469-474.

[2] National Arthritis Foundation. Arthritis Foundation: Press Release. Washington D.C. May 2, 1979.

[3] Massachusetts Medical Society. Occupational finger injuries United States, 1982.Morbiditya mortality weekly report 1983;32: 589-591.

[4] Hakkinen K. Safety in materials handling. Scand Journal work Environm Health 1981;4: 109-114.

[5] Coleman PJ. Injury surveillance. A review of data sources used by the Division of Safety Research Scand J Work Environ Health 1983;9: 128-135.

[6] Hale AR, Hale M. A review of the Industrial Accident Research Literature.London, HMSO, 1972.

[7] Saari J, Tech D, Lahtela J. Work conditions and accidents in three industries. Scand J Work Environ Healthg 1981;4: 97-105.

[8] Page RE. Hand injuies at work. The Hand 1995; 1: 51-55.

[9] Frogatt P. The influence of age on the accidentexperience of bus drivers. Annals of Occupational Hygiene 1962: 5 :

[10] Ong SG, Fung SC, Chow SP, Kleevens JWL. A study of major factors associated with severe occupational hand injury inHong Kong Island. J Sco OccupMed 1982;2: 82-88.

[II] Justis EJ, Moore SV, La Velie DG. Woodworking injuries. An epidemiological survey injuries Sustained using woodworking machinery and hand tools. J HandSurg Am 1987; 12: 890-895.

[12] Hakkinen K. The progress of technology and safety in materials handling.J Occup Accidents 1982;4: 157-163. 


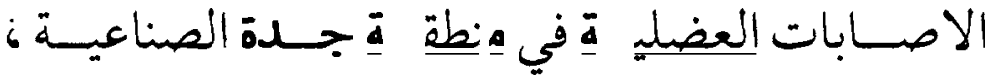

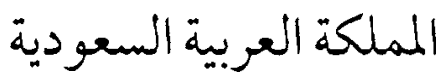

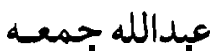 \\ قسم جراحه العظلم , كلية الطب والعلوم الطبية , جامعة الملك عبدالعزبز ,

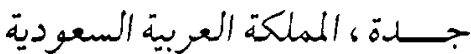

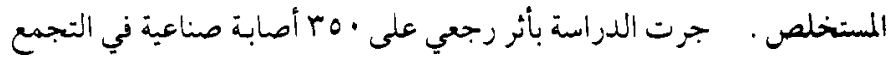

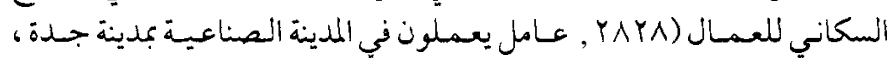

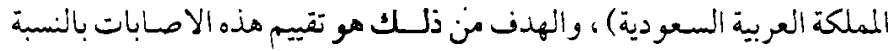

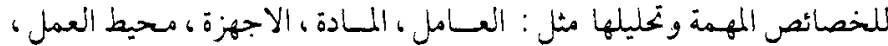

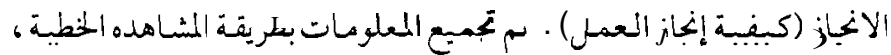

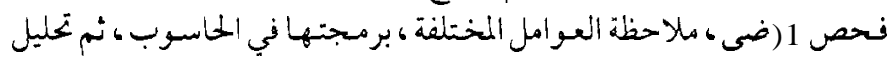

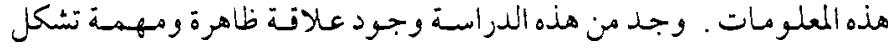

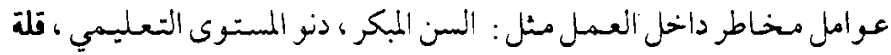

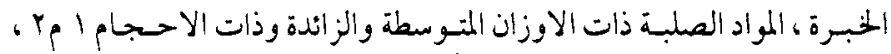

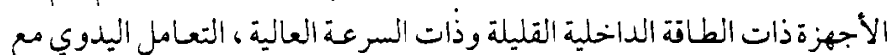

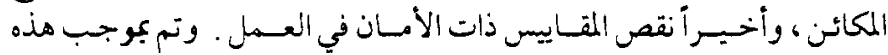

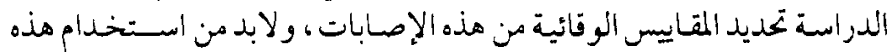

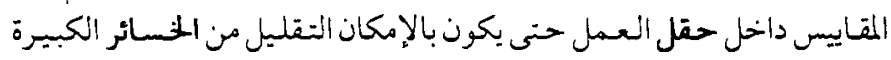

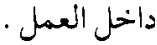

